\title{
Evaluation of antimicrobial resistance pattern of uropathogens in a tertiary care hospital in Dhaka city, Bangladesh
}

\author{
Azizun Nahar ${ }^{1}$, Shahed Hasnat ${ }^{2}$, Hasina Akhter ${ }^{3}$, Nilufar Begum $^{4}$
}

${ }^{1,2,3}$ Assistant Professor; ${ }^{4}$ Head of the Department; Department of Microbiology, Bangladesh Medical College, Dhaka, Bangladesh.

\begin{abstract}
Urinary tract infection (UTI) is one of the most common bacterial infections seen in developing countries like Bangladesh. This study is, therefore, designed to determine the bacterial uropathogens and their antibiotic resistance pattern among patients with complaints of UTIs in Dhaka city. This study was carried out in the laboratory of the Department of Microbiology, Bangladesh Medical College, Dhaka, Bangladesh from January to June 2015. A total of 2541 urine samples were collected in sterile containers from suspected urinary tract infected cases. A specimen was considered positive for UTI if an organism was cultured at a concentration of $\geq 10^{5} \mathrm{CFU} / \mathrm{ml}$ or when an organism was cultured at a concentration of $10^{4} \mathrm{CFU} / \mathrm{ml}$ and $>5$ pus cells per high power field. Antimicrobial susceptibility testing of the isolated bacterial species was performed by disc diffusion method following the National Committee for Clinical laboratory Standards (NCCLS) guidelines. A total of $303(11.92 \%)$ bacterial uropathogens were isolated from 2541 urine samples. Among the 303 isolates, majority of the isolates 197 (65.02\%) were from females. Both the age groups up to 18 years and above 18 years the highest prevalence was found in females $34(11.22 \%)$ and $163(53.79 \%)$ respectively. Most predominant organism was Escherichia coli 262(86.46\%)followed by Pseudomonas 12(3.96\%), Enterococci 12(3.96\%), Klebsiella11(3.63\%). Escherichiacoli showed very high resistance to amoxycillin $95.41 \%$, cefradin $90.45 \%$, nalidixic acid and Klebsiella to amoxycillin 90.90\%, nitrofurantoin 90.90\%. Again Pseudomonas was highly resistant to cefuroxime $100 \%$, cefexime $100 \%$ and ceftriaxone $83.33 \%$. Enterococci were found highly resistance to cefexime $91.66 \%$, cloxacillin $83.33 \%$, and erythromycin $83.33 \%$.Due to wide scale resistance of the drugs used to treat UTI, choice of drugs in the treatment of UTI is quite narrow. In country like ours awareness for prevention of UTI should be encouraged among the community level as it affects all age groups.
\end{abstract}

Keywords: Urinary tract infection, Uropathogens, Antibiogram, Antimicrobial resistance, Bangladesh.

\section{Introduction}

Urinary tract infection (UTI) is one of the most common bacterial infections seen in clinical practice particularly in developing countries with a high rate of morbidity and financial cost. ${ }^{1}$ It is the second most common infections in community practice with approximately 150 million diagnosed cases each year. ${ }^{2}$

UTI affect patients in all age groups and both sexes. ${ }^{3}$ Neonates, girls, young women and older men are most susceptible to UTIs. In women, bacterial cystitis is the most common bacterial infection. Every woman has a $60 \%$ lifetime risk of developing bacterial cystitis, which develops mostly before the age of $24{ }^{4}$ The most common pathogenic organism of UTI is Escherichia coli, which is responsible for more than $80 \%$ cases. ${ }^{5,6}$ Other pathogenic organisms of UTI are Staphylococcus saprophyticus, Staphylococcus aureus, Proteus sp., Klebsiella pneumoniae, Pseudomonas aeruginosa and Enterococci. ${ }^{{ }_{-9}}$

The resistance pattern of uropathogens is changing drastically, specifically in developing countries, such as Bangladesh because of uncontrolled and widespread use of antibiotics. Antibiotics are usually given empirically before the laboratory results of urine culture are available. To ensure appropriate therapy, current knowledge of the organisms that cause UTI and their antibiotic susceptibility is mandatory. ${ }^{10}$ Due to rising antibiotic resistance among uropathogens, it is important to have

\section{Practice Points}

- Urinary tract infection (UTI) is one of the most common bacterial infections in Bangladesh. Highest prevalence of UTI was found among the females having age 18 years and above.

- Among the pathogens Escherichia coli was found to be most common uropathogen.

- Culture sensitivity \& antibiogram is crucial for identification of pathogen and to institute proper treatment.

- Due to inappropriate use of antibiotics and lack of awareness among the patients are considered to be increased antimicrobial resistance.

- Antibiotic policy should be formulated by the government and should be strictly implemented by the physicians.

local hospital based knowledge of the organisms causing UTI and their antibiotic sensitivity patterns. The spectrums of etiologic agents causing UTIs and their antimicrobial resistance pattern have been continuously changing over the years, both in community and in hospitals. ${ }^{11}$

Increasing multidrug resistance in bacterial

Correspondence: Dr. Azizun Nahar, Assistant Professor, Department of Microbiology, Bangladesh Medical College, Dhaka, Bangladesh. E-mail: azizunnahar26@gmail.com. 
uropathogens is an important and evolving public health challenge. ${ }^{1,12}$ The prevalence of antimicrobial resistance in urinary pathogens is increasing worldwide. ${ }^{13}$ Accurate bacteriological records of culture results provide guidance on empirical therapy before sensitivity patterns are available. ${ }^{13,14}$ Since most UTIs are treated empirically, the criteria for the selection of antimicrobial agents should be determined on the basis of the most likely pathogens and its expected resistance pattern in a geographic area. ${ }^{1,15}$ Thus there is a need for periodic monitoring of causative agents of UTI and their resistance pattern in a given locality. ${ }^{1}$

This study is, therefore, designed to determine the bacterial uropathogens and their antibiotic sensitivity patterns among patients with complaints of UTIs in Dhaka city, Bangladesh.

\section{Materials and methods}

This cross-sectional study was carried out in the laboratory of the Department of Microbiology, Bangladesh Medical College, Dhaka, Bangladesh. The duration of the study was 6 months (January to June 2015). Patients admitted in inpatient department and visited the outpatient department of Bangladesh Medical College and Hospital Dhaka with suspected UTI cases was included in this study. Written consent was taken from the concerned authority.

Clean catch midstream and/or catheter catch urine sample was collected into a sterile container/test tube aseptically. The samples were processed according to a previously described methodology. ${ }^{16} \mathrm{~A}$ sterile platinum wired calibrated loop was used which delivered 0.001 $\mathrm{ml}$ of urine. A loopful urine sample was plated on Cystine-lactose-Electrolyte Deficient (CLED) agar media (Hi Media Laboratories, India). The inoculated plates were incubated at $37^{\circ} \mathrm{C}$ for 24 hours and extended to 48 hours in culture negative cases. The plates were then examined macroscopically for bacterial growth. A specimen was considered positive for UTI if an organism was cultured at a concentration of $\geq 10^{5} \mathrm{CFU} /$ $\mathrm{ml}$ or when an organism was cultured at a concentration of $10^{4} \mathrm{CFU} / \mathrm{ml}$ and $>5$ pus cells per high power field were observed on microscopic examination of the urine. ${ }^{17-19}$

Identification of bacterial pathogens was made on the basis of Gram reactions, morphology, motility test, biochemical and cultural characteristics. ${ }^{20}$ Antimicrobial susceptibility testing of the isolated bacterial species was performed by disc diffusion method following the National Committee for Clinical laboratory Standards (NCCLS) guidelines. ${ }^{21}$

All discs were obtained from Oxoid Ltd. Antibiotics used for uropathogens were amoxycillin $(10 \mu \mathrm{g})$, ciprofloxacin $(5 \mu \mathrm{g})$, gentamicin $(10 \mu \mathrm{g})$, cefradine $(30 \mu \mathrm{g})$, cefuroxime $(30 \mu \mathrm{g})$, cephalexin $(30 \mu \mathrm{g})$, cefexime $(5 \mu \mathrm{g})$, ceftriaxone $(30 \mu \mathrm{g})$, ceftazidime $(30 \mu \mathrm{g})$, cefepime $(30 \mu \mathrm{g})$, cotrimoxazole $(25 \mu \mathrm{g})$, micellinum $(25 \mu \mathrm{g})$, imipenem $(10 \mu \mathrm{g})$, meropenem $(10 \mu \mathrm{g})$, amikacin $(30 \mu \mathrm{g})$, nitrofurantoin $(300 \mu \mathrm{g})$, netilmicin $(30 \mu \mathrm{g})$, nalidixic acid $(30 \mu \mathrm{g})$, levofloxacin $(5 \mu \mathrm{g})$, piperacillin/ tazobactam $(110 \mu \mathrm{g})$, carbenicillin $(100 \mu \mathrm{g})$, aztreonam $(30 \mu \mathrm{g})$, colistin $(10 \mu \mathrm{g})$, cloxacillin $(5 \mu \mathrm{g})$, erythromycin $(15 \mu \mathrm{g})$, methicillin $(5 \mu \mathrm{g})$, vancomycin $(30 \mu \mathrm{g})$, linezolid

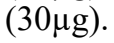

\section{Results}

Table 1 showed the age and sex distribution of the isolated pathogens. Among the 303 isolates, majority of the isolates $197(65.02 \%)$ were from females while the remaining were from male $106(34.98 \%)$. In both the age groups up to 18 years and above 18 years the highest prevalence was found in females $34(11.22 \%)$ and $163(53.79 \%)$ respectively.

Out of 2541 urine samples 303 (11.92\%) were bacterial isolates. Among them most predominant organism was Escherichia coli $262(86.46 \%)$ followed by Pseudomonas 12 (3.96\%), Enterococci 12 (3.96\%), Klebsiella 11 (3.63\%), Enterobacter 4 (1.32\%), Proteus 1 (0.33\%) and Staphylococcus aureus $1(0.33 \%)$ as shown in Table 2 .

Antimicrobial resistance pattern of uropathogens (Gram negative rods) had been shown in Table 3. Escherichia coli showed very high frequency of resistance to amoxycillin $95.41 \%$, cefradine $90.45 \%$, nalidixic acid $88.16 \%$, moderately high resistance to cefexime $61.83 \%$, cefuroxime $53.81 \%$, ciprofloxacin $52.29 \%$, cotrimoxazole $51.14 \%$, levofloxacin $50 \%$, ceftriaxone $44.65 \%$, cefepime $41.98 \%$ and low resistance to amikacin $7.63 \%$; imipenem $0.38 \%$; meropenem $1.14 \%$. Klebsiella was $90.90 \%$ resistant to amoxycillin as well as nitrofurantoin, $63.63 \%$ to nalidixic acid, $54.854 \%$ to cotrimoxazole, $45.45 \%$ to micellinum. Enterobacter was $100 \%$ resistant to cefradine, $75 \%$ resistant to micellinum, nalidixic acid, ciprofloxacin, $50 \%$ resistant to amoxicillin, cefexime, ceftriaxone, cotrimoxazole, gentamicin, $25 \%$ resistant to cefuroxime, nitrofurantoin, levofloxacin and netilmicin. Proteus was $100 \%$ resistant to amoxicillin, nalidixic acid, micellinum, nitrofurantoin, cotrimoxazole, ciprofloxacin and levofloxacin.

Antimicrobial resistance pattern of Pseudomonas was shown in Table 4. Pseudomonas was $100 \%$ resistant to cefuroxime and cefexime, $83.33 \%$ to ceftriaxone, $75 \%$ to netilmicin, $66.66 \%$ to carbenicillin, $58.33 \%$ to aztreonam, $41.66 \%$ to ceftazidime; amikacin; levofloxacin, $50 \%$ to colistin, $33.33 \%$ to ciprofloxacin. Low resistance showed in piperacillin/tazobactam $25 \%$, imipenem 25\% and meropenem 25\%.

Enterococci showed $91.66 \%$ resistance to cefexime, $83.33 \%$ to cloxacillin and erythromycin, $75 \%$ to ciprofloxacin and cotrimoxazole, $66.66 \%$ to cephalexin, $50 \%$ to cefradine; cefuroxime and methicillin, $25 \%$ to amoxicillin and vancomycin. Staphylococcus aureus

Table 1: Age and sex distribution of patients with positive UTI $(n=303)$

\begin{tabular}{|l|c|c|c|}
\hline \multirow{2}{*}{ Age (in years) } & \multicolumn{2}{|c|}{ Sex } & \multirow{2}{*}{ Total (\%) } \\
\cline { 2 - 3 } & Female (\%) & Male (\%) & $62(20.46 \%)$ \\
\hline Up to 18 & $34(11.22 \%)$ & $28(9.24 \%)$ & $241(79.54 \%)$ \\
\hline Above 18 & $163(53.79 \%)$ & $78(25.74 \%)$ & $303(100 \%)$ \\
\hline Total & $197(65.02 \%)$ & $106(34.98 \%)$ & 0 \\
\hline
\end{tabular}

South East Asia Journal of Public Health 2017;7(2):12-18 
Table 2: Pattern of bacteria isolated from urine culture $(n=303)$

\begin{tabular}{|l|c|}
\hline Isolated organisms & Number of isolates (\%) \\
\hline Escherichia coli & $262(86.46 \%)$ \\
\hline Pseudomonas & $12(3.96 \%)$ \\
\hline Enterococci & $12(3.96 \%)$ \\
\hline Klebsiella & $11(3.63 \%)$ \\
\hline Enterobacter & $4(1.32 \%)$ \\
\hline Proteus & $1(0.33 \%)$ \\
\hline Staphylococcus aureus & $1(0.33 \%)$ \\
\hline Total & 303 \\
\hline
\end{tabular}

were $100 \%$ resistant to amoxycillin, cefradine, cefuroxime, cephalexin, cefexime, cloxacillin, erythromycin and methicillin (Table 5).

\section{Discussion}

Urinary tract infection (UTI) is commonly experienced by women of various age groups especially elderly ones. They are mostly treated empirically and the criteria for the selection of antimicrobial agents should be determined on the basis of the most likely pathogen and its expected resistance pattern in the locality. 1,15 Thus, there is a need for periodic monitoring of the causative agents of UTI and their resistance/ susceptibility pattern in a locality.

UTI is more common in females than in males at different age groups and these findings of our study (Table 1) correlates with a study done in Bangladesh by Haque et al. ${ }^{22}$ In India, Prakash and Saxena found high prevalence of UTI in females $(73.57 \%)$ than in males $(35.14 \%)$ which also correlates with our study. ${ }^{1}$ The reason behind this high prevalence of UTI in females is due to close proximity of the urethral meatus to the anus, shorter urethra, sexual intercourse, incontinence and bad toilet. ${ }^{23-25}$

In this study, a total of $303(11.92 \%)$ bacterial uropathogens were isolated from 2541 urine samples. In our country $42.66 \%$ bacterial growth was isolated in other study and in India 53.81\% bacterial growth was isolated which were dissimilar with our study. ${ }^{22,1}$ Escherichia coli was found to be the predominant isolates $86.46 \%$ causing UTI, followed by Pseudomonas $3.96 \%$, Enterococci 3.96\%, Klebsiella 3.63\%, Enterobacter $1.32 \%$, Proteus $0.33 \%$ and Staphylococcus aureus $0.33 \%$ in our study (Table 2). Similar study in Bangladesh was previously reported by Jhora et al., who found the predominant isolated uropathogen was Escherichia coli $82.61 \%$ and others were Staphylococcuss saprophyticus 7.01\%, Klebsiella 3.86\%, Pseudomonas $3.14 \%$, Proteus $1.45 \%$, Staphylococcus aureus $0.24 \%{ }^{26}$ A study from Kathmandu, Nepal showed that Escherichia coli was the most prevailing organism (81.3\%). ${ }^{27}$ Another study done in India where Escherichia coli was $31.25 \%$, Pseudomonas $15.62 \%$, Proteus $15.62 \%$, Klebsiella $6.25 \%$ which did not correlate with our findings. ${ }^{28}$ This variation further supports the fact that the distribution of UTI-causing pathogens, including their antimicrobial susceptibility pattern, varies from place to place and changes from time to time. ${ }^{29}$

The studies on UTI in other places of the world also showed that Escherichia coli and Klebsiella spp. are the commonest uropathogens in UTI. ${ }^{30-34}$ Higher incidence of Gram negative bacteria, related to Enterobacteriaceae, in causing UTI has many factors which are responsible for their attachment to the uroepithelium. In addition, they are able to colonize in the urogenital mucosa with adhesions, pili, fimbriae and $\mathrm{P}-1$ blood group phenotype receptor. ${ }^{35}$

The present study showed the uropathogens as in Escherichia coli, Klebsiella, Proteus and Enterobacter were resistant to amoxicillin (Table 3) which correlates with a study done in Bangladesh by Haque et $a l^{22}$ The increasing level of abuse of drugs by the public, where patients indulge in antibiotic selfmedication, commonly to treat all kinds of infections, has been recorded as one significant way of promoting antibiotic resistance. ${ }^{36,37}$

In case of cephalosporin group, cefradine showed highest resistance to Escherichia coli $90.45 \%$; Enterobacter 100\%, cefuroxime showed resistance to Escherichia coli 53.81\%; Klebsiella 36.36\%; Enterobacter $25 \%$, cefexime showed resistance to Escherichia coli $61.83 \%$; Enterobacter 50\%; Klebsiella 27.27\%,

Table 3: Antimicrobial resistance pattern of Uropathogens (Gram negative rods)

\begin{tabular}{|l|c|c|c|c|}
\hline Drugs & $\begin{array}{c}\text { Esch. coli } \\
(\mathbf{n = 2 6 2})\end{array}$ & $\begin{array}{c}\text { Klebsiella } \\
(\mathbf{n = 1 1 )}\end{array}$ & $\begin{array}{c}\text { Enterobacter } \\
(\mathbf{n = 4 )}\end{array}$ & $\begin{array}{c}\text { Proteus } \\
(\mathbf{n}=\mathbf{1})\end{array}$ \\
\hline Amoxycillin & $250(95.41 \%)$ & $10(90.9 \%)$ & $2(50 \%)$ & $1(100 \%)$ \\
\hline Cefradine & $237(90.45 \%)$ & $4(36.36 \%)$ & $4(100 \%)$ & 0 \\
\hline Cefuroxime & $141(53.81 \%)$ & $4(36.36 \%)$ & $1(25 \%)$ & 0 \\
\hline Cefexime & $162(61.83 \%)$ & $3(27.27 \%)$ & $2(50 \%)$ & 0 \\
\hline Ceftriaxone & $117(44.65 \%)$ & $4(36.36 \%)$ & $2(50 \%)$ & 0 \\
\hline Cefepime & $110(41.98 \%)$ & $4(36.36 \%)$ & 0 & $1(100 \%)$ \\
\hline Nitrofurantoin & $67(25.57 \%)$ & $10(90.9 \%)$ & $1(25 \%)$ & $1(100 \%)$ \\
\hline Micellinum & $65(24.80 \%)$ & $5(45.45 \%)$ & $3(75 \%)$ & $1(100 \%)$ \\
\hline Cotrimoxazole & $134(51.14 \%)$ & $6(54.54 \%)$ & $2(50 \%)$ & $1(100 \%)$ \\
\hline Nalidixic acid & $231(88.16 \%)$ & $7(63.63 \%)$ & $3(75 \%)$ & $1(100 \%)$ \\
\hline Ciprofloxacin & $137(52.29 \%)$ & $3(27.27 \%)$ & $3(75 \%)$ & 0 \\
\hline Levofloxacin & $131(50 \%)$ & $3(27.27 \%)$ & $1(25 \%)$ & 0 \\
\hline Gentamicin & $78(29.77 \%)$ & $3(27.27 \%)$ & $2(50 \%)$ & 0 \\
\hline Amikacin & $20(7.63 \%)$ & 0 & 0 & $1(25 \%)$ \\
\hline Netilmicin & $51(19.46 \%)$ & $1(9.09 \%)$ & 0 & 0 \\
\hline Imipenem & $1(0.38 \%)$ & 0 & 0 & 0 \\
\hline Meropenem & $3(1.14 \%)$ & 0 & & 0 \\
\hline
\end{tabular}


Table 4: Antimicrobial resistance pattern of Uropathogen (Pseudomonas; $\mathrm{n}=12$ )

\begin{tabular}{|l|c|}
\hline Drugs & Pseudomonas (\%) \\
\hline Piperacillin/tazobactam & $3(25 \%)$ \\
\hline Carbenicillin & $8(66.66 \%)$ \\
\hline Cefuroxime & $12(100 \%)$ \\
\hline Cefexime & $12(100 \%)$ \\
\hline Ceftriaxone & $10(83.33 \%)$ \\
\hline Ceftazidime & $5(41.66 \%)$ \\
\hline Ciprofloxacin & $4(33.33 \%)$ \\
\hline Levofloxacin & $5(41.66 \%)$ \\
\hline Amikacin & $5(41.66 \%)$ \\
\hline Netilmicin & $9(75 \%)$ \\
\hline Aztreonam & $7(58.33 \%)$ \\
\hline Imipenem & $3(25 \%)$ \\
\hline Meropenem & $3(25 \%)$ \\
\hline Colistin & $6(50 \%)$ \\
\hline
\end{tabular}

ceftriaxone showed resistance to Escherichia coli $44.65 \%$; Enterobacter 50\%; Klebsiella $36.36 \%$ and cefepime showed resistance to Escherichia coli 41.98\%; Klebsiella $36.36 \%$ in this study, similar picture is also noted in a study in case of cephalosporin group. ${ }^{22}$ The high rate of resistance against third generation cephalosporin (Klebsiella $79.31 \%$ and Proteus $92.86 \%$ ) was observed by other study done in India. ${ }^{1}$

It is reasonable to speculate that there were ESBLproducing uropathogens especially from Gram negative isolates that couldn't be separated in the present investigation due to limitation are thought to be responsible for resistance to different generations of cephalosporin. ${ }^{38,31}$

Nitrofurantoin was found to be reasonably high efficacious agent among all antimicrobials used to almost all uropathogens in a study in Bangladesh which does not correlates with our study. ${ }^{22}$ In Nigeria greater percentage of the UTI isolates were sensitive to nitrofurantoin, it would be an excellent choice for UTI empiric therapy while awaiting the result of culture and sensitivity tests.

Ciprofloxacin was once considered to be the drug of choice for uncomplicated and complicated UTI but due to lack of rational use, this broad spectrum molecule has entirely lost its efficacy not only in UTI but to other common infections too. ${ }^{38,31}$ So, empiric use of fluoroquinolones should be restricted.

Regarding fluoroquinolone group, this study showed the higher resistance to nalidixic acid among uropathogens as in Proteus 100\% and Escherichia coli 88.16\%; resistance to ciprofloxacin were $100 \%$ in Proteus and $75 \%$ in Enterobacter and resistance to levofloxacin was $100 \%$ in Proteus. This finding is alarming for the clinician to treat UTI. It is a great concern for them to choose effective drugs against organisms causing UTI. This high rate of resistance against fluoroquinilones was also suggested by other studies done in India, Spain, Iran and Europe., ${ }^{1,40,41}$ Our finding did not correlate with others where organisms showed higher sensitivity. ${ }^{16,42-45}$

Gram negative rods were highly resistant to cotrimoxazole in this study which co-relate with another finding done in Bangladesh. ${ }^{22}$ Regarding aminoglycosides, Gram negative rods showed low resistance in our study which was similar with a study done in Bangladesh. ${ }^{22}$ It might
Table 5: Antimicrobial resistance pattern of Uropathogens (Gram positive cocci)

\begin{tabular}{|l|c|c|}
\hline Drugs & $\begin{array}{c}\text { Enterococci } \\
(\mathbf{n = 1 2})\end{array}$ & $\begin{array}{c}\text { Staphylococcus } \\
\text { Aureus }(\mathbf{n}=\mathbf{1})\end{array}$ \\
\hline Amoxycillin & $3(25 \%)$ & $1(100 \%)$ \\
\hline Cefradine & $6(50 \%)$ & $1(100 \%)$ \\
\hline Cefuroxime & $6(50 \%)$ & $1(100 \%)$ \\
\hline Cephalexin & $8(66.66 \%)$ & $1(100 \%)$ \\
\hline Cefexime & $11(91.66 \%)$ & $1(100 \%)$ \\
\hline Cloxacillin & $10(83.33 \%)$ & $1(100 \%)$ \\
\hline Ciprofloxacin & $9(75 \%)$ & 0 \\
\hline Cotrimoxazole & $9(75 \%)$ & 0 \\
\hline Imipenem & 0 & 0 \\
\hline Meropenem & 0 & 0 \\
\hline Erythromycin & $10(83.33 \%)$ & $1(100 \%)$ \\
\hline Methicillin & $6(50 \%)$ & $1(100 \%)$ \\
\hline Vancomycin & $3(25 \%)$ & 0 \\
\hline Linezolid & 0 & 0 \\
\hline
\end{tabular}

be due to their limited use because of parenteral use.

Imipenem and meropenem were used in this study and found to be most sensitive drugs against all isolated uropathogens. Both the drugs were $100 \%$ sensitive to Klebsiella, Enterobacter, Proteus, but Escherichia coli was $0.38 \%$ and $1.14 \%$ resistant to imipenem and meropenem respectively. Imipenem and meropenem were found to be $98 \%$ and $100 \%$ sensitive against highly resistant Gram negative bacilli, found in another study. ${ }^{46}$ In King Fahd Hospital, Saudi Arabia showed that meropenem and imipenem were $95.8 \%$ and $91.71 \%$ sensitive respectively against Gram negative rods. ${ }^{47}$

According to our study, Pseudomonas in UTI patients showed higher resistance to cefuroxime, cefexime, ceftriaxone and netilmicin (Table 4). Lowest resistance showed in pipercillin/tazobactam as well as in Carbapenem group. Low resistance to pepercillin/tazobactam possibly due to the batalactamase inhibitor in addition to the extended-spectrum nature and rare use of the drug. ${ }^{48}$ In Bangladesh, another study done in Square hospital, Dhaka (November 2011 to February 2013) showed resistance to imipenem $90 \%$, meropenem $90 \%$, gentamicin $60 \%$, amikacin $60 \%$, ciprofloxacin $50 \%$, cefepime $60 \%$, co-trimoxazole $10 \%$ but $100 \%$ sensitive to cefixime and ceftriaxone in Pseudomonas which does not correlate with our study. ${ }^{49}$ In India, Prakash and Suxena found resistant to ceftriaxone $95 \%$, amikacin 95\%, nitrofurantoin 90\%, nalidixic acid $85 \%$, ceftazidime $65 \%$, levofloxacin $40 \%$, netilmicin $20 \%$, gentamicin $10 \%$, cotrimoxazole 5\%, imipenem 5\% but meropenem were $100 \%$ sensitive in case of Pseudomonas. In Pakistan, Shah found that, Pseudomonas was resistant to cefuroxime $99.2 \%$, nalidixic acid $98.8 \%$, cefepime $63.9 \%$, ceftriaxone $61.7 \%$, ceftazidime $56.1 \%$, ciprofloxacin $50 \%$, gentamicin $35.3 \%$, amikacin $25.3 \%$, piperacillin/tazobactam $19.6 \%$ \& imipenem $10.4 \%$.

Though some antibiotic sensitivity discs are not used in our laboratory against Pseudomonas but 
some studies showed higher sensitivity to cotrimoxazole, gentamicin and ofloxacin to this organism. $^{1,48}$

Over the last decade there has been a substantial increase in resistance of uropathogens to antibiotics. Resistance rates among Staphylococcus aureus strains are increasing and a major part of this species has become resistant to bata-lactamase resistant penicillin, for such resistant species, vancomycin is the effective choice of drug. ${ }^{50,51}$ Staphylococcus aureus and Enterococcus both were resistant to amoxycillin, cloxacillin, cephalosporins, erythromycin in a variable percentage in this study (Table 5).

Resistance to vancomycin is reported among Enterococ$c i$, but this resistance has also begun to develop among Staphylococci. ${ }^{52-54}$ We concentrated on resistance to vancomycin and resistant strains to vancomycin were observed in case of Enterococci 25\%. Staphylococcus aureus was $100 \%$ sensitive to ciprofloxacin and cotrimoxazole but Enterococcus was $75 \%$ resistant to these drugs in this study. Haque et al., found similar findings like us in case of Enterococcus. ${ }^{22}$ Our finding does not match with another study done in India by Shalini et al., who found Staphylococcus aureus was resistant to cotrimoxazole $46.15 \%$ and ciprofloxacin $22.2 \%{ }^{55}$ Another study in India by Prakash \& Saxena found Staphylococcus aureus was sensitive to gentamicin $80 \%$, levofloxacin $73.33 \%$, netilmicin 93.33\% and ceftriaxone $93.33 \%{ }^{1}$ In Bangladesh, Saha showed Staphylococcus aureus $100 \%$ sensitive to amikacin, ceftriaxone and ciprofloxacin. ${ }^{56}$

Staphylococcus aureus and Enterococci both were $100 \%$ sensitive to imipenem, meropenem and linezolid in our study. Another study in Square Hospital, Dhaka Bangladesh (November 2011 to February 2013) found $93.3 \%$ resistant to imipenem and meropenem which does not correlate with our study. ${ }^{49}$ So, UTI caused by Gram positive cocci may be treated by linezolid, vancomycin, imipenem and meropenem according to the finding of this study.

The higher antibiotic resistance in the present study might be due to the fact that common antibiotics are sold over the counter in Bangladesh and people of any age can buy them without doctor's prescription. Antimicrobial drug resistance is a burning issue in national and global perspective. Highest incidence and prevalence of UTI is observed in developing countries like us. So, government should formulate drug policy especially regarding antibiotic among the chemist and the users.

\section{Limitations}

ESBL producing bacteria was not detected in our study leading to inappropriate use of antibiotic and treatment failure.

\section{Conclusion}

Due to wide scale resistance of the drugs used to treat UTI, choice of drugs in the treatment of UTI is quite narrow. In country like Bangladesh, awareness for prevention of UTI should be encouraged among the community level as it affects all age groups. A strong antimicrobial stewardship program is needed which is followed by the physicians. An infection control measure is must to control infection and to prevent the spread of these notorious drug resistant organisms.

\section{Competing interest}

The authors declare that they have no competing interests.

\section{References}

1. Prakash D, Saxena RS. Distribution and antimicrobial susceptibility pattern of bacterial pathogens causing urinary tract infection in Urban Community of Meerut City, India. ISRN Microbiol 2013;2013:749629.

2. Akram M, Shahid M, Khan AU. Etiology and antibiotic resistance patterns of communityacquired urinary tract infections in $\mathrm{J} \mathrm{N} \mathrm{M} \mathrm{C}$ Hospital Aligarh, India. Ann Clin Microbial Antimicrob 2007;6:4.

3. Gupta KAD, Hooton CL, Wobe, Stamm WE. The prevalence of antimicrobial resistance among uropathogens causing uncomplicated cyctitis in young women. Int $J$ Antimicrob Agents 1999;11(3-4):305-8.

4. Nicole W, Jon DM. Deciphering Dysuria. Emerg Med 2008; 40(10):29-34.

5. Blondeau JM. Current issues in the management of urinary tract infections: extended-release ciprofloxacin as a novel treatment option. Drugs 2004 64(6):611-28.

6. National Committee for Clinical Laboratory Standards. Performance standards for antimicrobial disc susceptibility tests. $7^{\text {th }}$ ed. Pennsylvania: NCCLS, 2000.

7. Salek SB. Infective Syndrome in Medical Microbiology. $4^{\text {th }}$ edition Texas: University of Texas Medical Branch, 1996.

8. Kolawole AS, Kandaki-Olukemi YT, Babatunde SK, Durowade KA, Kolawole CF. Prevalence of urinary tract infections among patients attending Dalhatu Araf Specialist hospital, Lafia, Nasarawa State, Nigeria. Int J Med Sci 2009; 1(5):1637.

9. Khorvash F, Mostafavizadeh K, Mobasherizadeh S, Behjati M. A comparison of antibiotic susceptibility patterns for Klebsiella associated urinary tract infection in spinal cord injured patients with nosocomial infection .Acta Medica Iranica 2009; 47(6):447-50.

10. Tankhiwale SS, Jalgaonkar SV, Ahamad S, Hassani U. Evaluation of extended spectrum beta lactamase in urinary isolates. Indian $\mathrm{J}$ Med Res 2004;120(6):553-56.

11. Kahimeter G. ECO.SENS. An international survey of the antimicrobial susceptibility of pathogens from uncomplicated urinary tract infections: the ECO.SENS Project. $J$ Antimicrobial Chemother 2003; 51: 69-76.

12. Newell A, Riley P, Rodgers M. Resistance 
patterns of urinary tract infections diagnosed in a genitourinary medicine clinic. Int $J$ STD AIDS 2000;11(8):499-500.

13. Orrett FA, Shurland SM. The changing patterns of antimicrobial susceptibility of urinary pathogens in Trinidad. Singapore Med J 1998;39 (6):256-9.

14. Ochada N, Nasiru I, ThairuY, Okanlowan M, Abdulakeem Y. Antimicrobial susceptibility pattern of urinary pathogens isolated from two tertiary hospitals in Southwestern Nigeria. Afr $J$ Clin Exp Microbiol 2014;16(1):12.

15. Uwaezuoke JC, Ogbulie JN. Antibiotic sensitivity pattern of urinary tract pathogens in Port-Harcourt, Nigeria. JA SEM 2006;10(3):1037.

16. Ehinmidu JO. Antibiotics susceptibility patterns of urine bacterial isolates in Zaria, Nigeria. Trop J Pharm Res 2003;2(2):223-8.

17. Collee JG, Miles RS, Watt B. Tests for the identification of bacteria. In: Collee JG, Fraser AG, Marmion, Simmon A (Eds). Makie and Mc Cartney Practical Medical Microbiology. $14^{\text {th }}$ edition. London: Churchill Livingstone, 1996.

18. Bonadio M, Meini M, Spetaleri P, Gilgi C. Current microbiological and clinical aspects of urinary tract infections. Eur J Urol 2001; 40:43945 .

19. Collee JG, Duguid JP, Fraser AG, Marmion BP, Simmons A. Laboratory Strategy In The Diagnosis of infective Syndromes. In: Collee JG, Fraser AG, Marmion, Simmon A (Eds). Makie and Mc Cartney Practical Medical Microbiology. $14^{\text {th }}$ edition London: Churchill Livingstone, 1996.

20. Cheesbrough M. Medical Laboratories Manual for Tropical Countries: Microbiology Vol 2. London: Elsevier Health Sciences, 1995.

21. National Committee for Clinical laboratory Standards. Performance Standards for antimicrobial Susceptibility testing, 11th informational Supplement, NCCLS document M100-S11.. Pennsylvania: NCCLS), 2001

22. Haque R, Akhter ML, Salam MA. Prevalence and susceptibility of uropathogens: A recent report from a teaching hospital in Bangladesh. BMC Research Notes 2015;8:416.

23. Ochei J, Kolhatkar A. Medical Laboratory Science: Theory and Practice. $1^{\text {st }}$ edition New Delhi: McGraw-Hill, 2000.

24. Aiyegoro OA, Igbinosa OO, Ogunmwonyi IN, Odjadjaro E, Igbinosa OE, Okoh AI. Incidence of urinary tract infections (UTI) among children and adolescents in Ile-Ife, Nigeria. Afr J Microbiol Res 2007; 1(2):13-9.

25. Orrett FA, Davis GK. A comparison of antimicrobial susceptibility profile of urinary pathogens for the years, 1999 and 2003. West Indian Med $J$ 2006; 55(2):95-9.

26. Jhora ST, Paul S. Urinary tract infections caused by Staphylococcus saprophyticus and their antimicrobial sensitivity pattern in young adult women. Bangladesh J Med Micribiol 2011;5 (1):21-5.

27. Kamenski G, Wagner G. Zehetmayer S, Fink W, Spiegel W, Hoffmann K. Antibacterial resistances in uncomplicated urinary tract infections in women; ECO. SENS II data from primary health care in Australia. BMC Infect Dis 2012;12:222.

28. Wasnik DD, Tumane PM. Prevalence and antibacterial susceptibility pattern of urinary tract infection causing human pathogenic bacteria. Asian J Biomed Pharmaceut Sci 2012;2(15):1-3.

29. Okonko IO, Ijandipe LA, Ilusanya OA, Donbraye-Emmanuel OB, Ejembi J, Udeze AO, Egun OC, Fowotade A, Nkang AO. Incidence of urinary tract infection (UTI) among pregnant women in Ibadan, South-Western Nigeria. Afr $J$ Biotechnol 2009; 8(23):6649-57.

30. Akram M, Shahid M, Khan AU. Etiology and antibiotic resistance patterns of community-acquired urinary tract infections in $\mathbf{J}$ N M C Hospital Aligarh, India. Ann Clin Microbiol Antimicrob 2007;6:4.

31. KothariA,Sagar V. Antibiotic resistance in pathogens causing community-acquired urinary tract infections in India: a multicenter study. $J$ Infect Dev Ctries 2008; 2(5):354-8.

32. Selvakumar BN, Jasmine R. Antibiotic susceptibility of ESBL-producing urinary isolates at a Tertiary Care Hospital in Tiruchirappalli South India. J Med Sci 2007;7 (3):443-6

33. Bahadin J, Teo SSH, Mathew S. Aetiology of community-acquired urinary tract infection and antimicrobial susceptibility patterns of uropathogens isolated. Singapore Med J 2011;52 (6):415-20.

34. Bano K, Khan J, Begum RH, Begum H, Munir S, Akbar N, Ansari JA, Anees M. Patterns of antibiotic sensitivity of bacterial pathogens among urinary tract infections (UTI) patients in a Pakistani population. Afr J Microbiol Res 2012; 6:414-20.

35. Das RN, Chandrashekhar TS, Joshi HS, Gurung M, Shrestha N, ShivanandaPG. Frequency and susceptibility profile of pathogens causing urinary tract infections at a tertiary care hospital in western Nepal. Singapore Med J 2006; 47 (4):281-5.

36. Ugwu MC, Ikegbunam MN, Nduka SO, Attama AA, Ibezim EC, Esimone CO. Molecular characterization and efficacy of antibiotic combinations on multiple antibiotic-resistant Staphylococcus aureus isolated from nostrils of healthy human volunteers. Int $J$ Pharm Sci 2013;5(1):26-32.

37. Ejikeugwu C, Ugwu M, Iroha I. Malachy U, Ifeanyichukwu I, Thaddeus G, Carissa D, Peter E, Charles E. Detection and antimicrobial susceptibility of some gram negative bacteria producing carbapenemases and extended spectrum $\beta$-Lactamases. Int J Microbiol Immunol Res 
2013; 2(6):64-9.

38. Sharifian M, Karimi A, Rafiee-Tabatabaei S, Anvarpour N. Microbial sensitivity pattern in urinary tract infections in children: a single center experience of 1177 urine cultures. Jpn $J$ Infect Dis 2006;59:380-2.

39. Ekwealor PA, Malachy CU, Ezeobi I, Amalukwe G, Ugwu BC, Okezie U, Stanley C, Esimone C. Antimicrobial Evaluation of Bacterial Isolates from Urine Specimen of Patients with Complaints of Urinary Tract Infections in Awka, Nigeria. J Int J Microbiol 2016; 2016.9740273.

40. Rashedmarandi FRM, Saremi M. A survey on urinary pathogens and their antimicrobial susceptibility among patients with significant bacteriuria. Iran J Pathol 2008; 3:191-6.

41. Gobernado M, Valdés L, Alós JI, García-Rey IC, Dal-RéR,García-de-Lomas J. Antimicrobial susceptibility of clinical Escherichia coli isolates from uncomplicated cystitis in women over a 1year period in Spain. Rev Esp Quimioter 2007; 20(1):68-76.

42. Ebie MY, Kandaki-Olukemi YT, Ayanbadejo J, Tanyigna KB.UTI infections in a Nigerian Military Hospital. Nig J of Microbiol 2001;15 (1):31-7.

43. Theodore M. Prevalence and antibiogram of urinary tract infections among prison inmates in Nigeria. Internet J Microbiol 2007; 3(2):1-5.

44. Krumperman PH. Multiple antibiotic resistance indexing of Escherichia coli to identify high-risk sources of fecal contamination of foods. Appl Environ Microbiol 1983; 46(1):165-70.

45. Burbige KA, Retic AB, Colony A, Bauer SB, Lebowitz R. UTI in boys. J Urol 984; 132:541-2.

46. Joly-Guillou ML, Kempf M, Cavallo JD, Chomarat $M$, Dubreuil L, Maugein $J$, Muller-Serjeys $\quad C$, Roussel-delvallez $M$. Comparative in vitro activity of Meropenem, Imipenem and Piperacillin/tazobactam against 1071 clinical isolates using 2 different methods: a French multicenter study. BMC Infect Dis 2010;10:72.
47. Al-Zahran AJ, Akhtar N. Susceptibility patterns of extended spectrum beta-lactamase (ESBL)producing Escherichia coli and Klebsiella pneumoniae isolated in a teaching hospital. Pak $J$ Med Res 2005; 44:64-7.

48. Shah DA, Wasim S, Abdullah FE. Antibiotic resistance pattern of Pseudomonas aeruginosa isolated from urine samples of urinary tract infections patients in Karachi, Pakistan. Pak $J$ Med Sci 2015;31(2):341-5.

49. Biswas R, Rabbani R, Ahmed HS, Sarker MAS Zafrin N, Rahman MM. Antibiotic sensitivity pattern of urinary tract infection at a tertiary care hospital Bangladesh. Crit Care J 2014;2(1):21-4.

50. Bogaard AE, London N, Driessen C, Stobberingh EE. Antibiotic resistance of faecal Escherichia coli in poultry, poultry farmers and poultry slaughterers. J Antimicrob Chemother 2001;47:763-71.

51. Karbasizaed V, Badami N, Emtiazi G. Antimicrobial, heavy metal resistance and plasmid profile of coliforms isolated from noso-comial infections in a hospital in Isfahan, Iran. Afr J Biotechnol 2003;2:379-83.

52. Williams JD. Antibiotic resistance: who needs control over antibiotic use - community doctors, farmers or hospital practitioners? Newsl Int Soc Chemoth 2001;5:4.

53. Alebouyeh M, AmirmozafariN, Forohesh $\mathrm{H}$. Evaluation of virulence factors and plasmidrelated transmissibility among different isolates of enterococci. Iran Biomed J 2005;9:51-5.

54. Murray BG. The life and times of the Enterococcus. Clin Microbiol Rev 1990;3:46-65.

55. Shalini, Joshi MC, Rashid MK, Joshi HS. Study of antibiotic sensitivity pattern in urinary tract infection at a tertiary hospital. Natl J Integr Res Med 2011; 2(3):43-6.

56. Saha S, Rahman MS, Hassan MN, Sarker S, Islam MK, Saha P, Alam B, Sultana N, Rahman KMT, Sumi SS, Islam MF, Hasan S. Antimicrobial resistance in uropathogen isolates from patients with urinary tract infections. Biomed Res Ther 2015;2(5):263-9. 